\title{
Effects of Command and Guided Discovery Teaching Styles on Retention of a Psychomotor Skill
}

\author{
Dr. R. Arjunan ${ }^{1}$, Dr. R. Jayachandran ${ }^{2}$ \\ ${ }^{I}$ (Associate Professor, Dept. of Physical Education \& Health sciences, Alagappa University, Karaikudi, India \\ 630004) \\ 2 (Director of Physical Education, Poompuhar College, Melaiyur, Sirkazhi (Taluk) Nagapttinam (District) \\ India- 609107)
}

\begin{abstract}
The main purpose of the study was to identify the effect of command and guided discovery teaching styles in retention of skill of ball-bouncing (dribbling) and to assess the trend and effect of command and guided discovery teaching styles in retention of ball-bouncing skill (dribbling). Two groups with two experimental conditions were followed; this consisted of command and guided discovery-teaching styles. For this purpose two experimental groups were employed. To accomplish this task it was decided to utilize 18 fifth standard students. The randomly selected students were in the age group of nine and ten. The students randomly selected from each group were assigned randomly to the two experimental conditions, command and guided discoveryteaching styles. The samples of command and guided discovery groups were treated by command and discovery style teaching of the skill of ball-bouncing for a period of 12 weeks respectively, three days per week in alternate days. Test on the skill of ball-bouncing was conducted prior to the treatment (Pre-test), end of fourth week, end of eighth week and at the end of the treatment (twelfth week-post-test). This twelve-week period was considered as acquisition period. Retention period was four weeks. On thirteenth, fourteenth and sixteenth week again test on the skill of ball-bouncing was administered. This four-week period formed retention period. In the initial data analysis, ' $F$ ' test (ANACOVA) was applied to the pre-test and post-test means among the groups on acquisition and retention of the skill of ball-bouncing. To test the sources for significant changes of command and guided teaching style on retention, the Scheffe's post-hoc test was applied. The following conclusions were drawn from the obtained results.

1. The practice of scientifically structured twelve weeks of command and guided discovery teaching style may help to acquire the skill of ball-bouncing.

2. Eight weeks of command and guided discovery teaching style may be sufficient to acquire the skill of ballbouncing.

3. For the retention of the acquired psychomotor skill under the guided discovery style, a child-centered teaching approach is superior when compared with command style teaching approach, a teacher-centered teaching approach.

Hence it is recommended to include formal physical education programme in the form of movement education in the curriculum of primary school children in India and training in child-centered teaching styles may be included in the Physical Education Teacher Education curriculum.
\end{abstract}

Keywords: Command style, Guided Discovery Style, Retention, Teaching Style, Psychomotor.

\section{Introduction}

The main purpose of the study was to compare the effectiveness of a traditional teaching approachcommand style of teaching, with a modern teaching approach-guided discovery style, on retention of the skill of ball-bouncing (dribbling)-a psychomotor skill. Command style also referred as direct teaching approach, teacher-centered teaching style and reproductive teaching style is called indirect teaching approach, childcentered teaching style and productive teaching style. The skill of ball-bouncing is chosen as it is recommended to be acquired in the formative years of primary school children. Moreover, the advocates of guided discovery style recommend that it is more suitable for the primary school children. While scanning through related literature $^{1,2,3, \text { and } 4}$ it was found that both the teacher-centered and child-centered teaching styles were effective in acquisition of discrete skills. However, on retention and transfer of learning count, the child-centered approach had an advantage.

In India only reproductive style of teaching is being followed and the child-centered teaching approach is nowhere heard off. Moreover, National Curriculum of India recommends formal physical education instruction for Middle, High and Higher Secondary school children. The primary school children are the neglected lot. As such the present investigator was motivated to undertake this study using the primary school children as subjects. 
India is a country of collectivist cultures. Collectivist cultures ${ }^{5}$ are those in which conformity and group needs are cultural priorities. Further, India adopted and followed a national curriculum. As India is a country of collectivist cultures, education in any field is teacher- centered, as the curriculum planners, administrators and teachers believe in the importance of standard information presentation and student performance. Indian National Curriculum is a centralized system, where reproductive style of teaching is followed. While going through all Physical Education Teacher Education (PETE) curricula, the method prescribed for teaching physical education is reproductive, command and drill styles (teacher-centered).

With the demands of national curricula and educational mandates, the teachers in India are forced to choose teacher-centered teaching styles. First physical education teachers are not trained in productive teaching styles. It is also not familiar to them. Secondly, productive styles of teaching (child-centered teaching style) are viewed as a threat to student control, as students would not be engaged in the same task, or producing similar outcome with those styles.

\section{Purpose of the Study}

1. To identify the effect of command and guided discovery teaching styles in acquisition and retention of ball-bouncing skill (dribbling).

2. To assess the trend and effect at various stages - end of Fourth week, end of eighth week, end of 12th week (Acquisition Period), end of 13th week end of 14th week and end of 16th week (Retention Period) of command and guided discovery teaching styles in acquisition and retention of ball-bouncing skill (dribbling).

\section{Experimental Design}

Two groups with two experimental conditions were followed; this consisted of command and guided discovery-teaching styles. For this purpose two experimental groups were employed.

The following variables were studied:

1. The independent variables, with command and guided discovery style teaching.

2. The dependent variables, with retention of a psychomotor skill. Here in this study, the skill of ball-bouncing was used as motor skill.

To accomplish this task it was decided to utilize 18 fifth standard students of St. Antony's and Sengunther Matriculation Schools, Tiruchengode, Namakkal, District, Tamil Nadu. The randomly selected students were in the age group of nine and ten. It was ensured that the subjects were medically fit to undergo the experimental requirement of the present study through medical examination. Prior to the start of the experiment, informed consent was obtained from the parents and the school administration to undergo the rigid requirement of the experimental procedures, testing as well as teaching schedule.

\subsection{Sampling}

The students randomly selected from each group were assigned randomly to the two experimental conditions, command and guided discovery-teaching styles. Selection of different schools for each group of treatment was purposely done to eliminate inter-group interaction effect during the experimental period.

\subsection{Procedures}

The samples of command and guided discovery groups were treated by command and discovery style teaching of the skill of ball-bouncing for a period of 12 weeks respectively, three days per week in alternate days. The students were allowed to participate in other school recreational programmes.

Test on the skill of ball-bouncing was conducted prior to the treatment (Pre-test), end of fourth week, end of eighth week and at the end of the treatment (twelfth week -post-test). This twelve-week period was considered as acquisition period. Retention period was four weeks. On thirteenth, fourteenth and sixteenth week again test on the skill of ball-bouncing was administered. This four-week period formed retention period.

\subsection{Development of the programme}

3.3.1. Pilot Study

In order to ascertain the suitability of the material and to find out relative effectiveness of the two methods of teaching two pilot studies were conducted: A single subject-try-out and five subject pilot study. The pilot study was undertaken for the following purposes:

1. To try out the instructional materials prepared by the investigator and to find out as to which standard it was most suitable.

2. To find out the adequacy and the feasibility of the measurement tools selected.

3. To refine and modify the instruction materials, if need be.

4. To acquire better insight into the problems of selection of sample, design, collection and analysis of data. 
5. To determine the optimum number of periods as well as the length of time required for the completion of the study.

Based on the findings of pilot study, both the experimental groups attended the same number of training session. Both the experimental groups followed the command and guided discovery style training programme on Mondays, Wednesdays and Fridays. This training programme comprised twelve weeks of 35 minutes session each. From 13th week to 16th week no treatment was administered as it was considered as retention period.

\subsection{Format of the Lesson Plan}

Each lesson plan was divided into four instructional parts as follows:

1. Introductory Activity

2. Fitness Development Activity

3. Lesson Focus Activities

The objective of the lesson focus activity was to dribble a junior basketball in general space under control by pushing the ball slightly ahead with fingertips, below waist height, looking up to avoid objects and protecting the ball by keeping the body between the ball and an object. In command teaching style nine learning stages were identified in the acquisition of the skill of ball-bouncing with 36 lesson units in total. Three problem-solving stages were identified in guided discovery style with 36 lesson units in total. It took ten to fifteen minutes of the 35 minutes lesson time.

$4 \quad$ Game Activity

\section{Results}

In the initial data analysis, ' $F$ ' test (ANACOVA) was applied to the pre-test and post-test means among the groups on acquisition and retention of the skill of ball-bouncing. The ' $\mathrm{F}$ ' value needed for significance among the means was 4.209 at 0.05 levels with 1 and 28 degrees of freedom.

The obtained ' $F$ ' value for the pre-test means of acquisition was 0.478 . The ' $F$ ' value observed on the criterion variable was not significant, since it fails to reach the significant level. Thus, this analysis indicates that the random assignment of subjects into two groups was successful.

The observed ' $F$ ' value for the post-test means of acquisition was 3.097. The ' $F$ ' value observed on the criterion variables was not significant, since it fails to reach the significant level. The mean difference between command and guided discovery on acquisition post-test means was statistically insignificant.

The observed ' $\mathrm{F}$ ' value (Table I) for the adjusted means between the two groups on acquisition was 17.722. Since the observed ' $F$ ' values on criterion measures were greater than the tabulated value (4.209, $\mathrm{Df}=1$ and 28). The observed mean difference among the two groups was statistically significant. It was observed that due to two different styles, command and guided discovery, the skill of ball bouncing improved.

The obtained ' $F$ ' value (Table I) for the pre-test mean was 3.097. The ' $F$ ' value obtained on the variables was not significant since it fails to reach significant level. Thus it was concluded that there was no significant difference among the command and guided discovery teaching style groups on variables used in the study before the treatment. Thus, this analysis indicates that the quantity of acquisition of dribbling skill of both command and guided discovery style were same. Hence there was no significant difference were observed between both the groups after the end of acquisition period.

The obtained ' $F$ ' values (Table I) for the post-test means were 14.051. This value was compared to the critical value of 4.209 at 0.05 levels of significance. It was observed that the ' $F$ ' value of post-test mean of retention was highly significant. The mean difference between command and guided teaching styles teaching groups on retention post-test means was statistically highly significant.

The F-Value obtained from testing the adjusted means among the two groups on retention measures were shown in table I. This was also represented in figure 5and 6 . The corresponding ' $\mathrm{F}$ ' value $(\mathrm{df}=1 \& 27)$ needed for significance of 0.05 level is 4.221 . The calculated ' $F$ ' value 26.048 was higher than the table value of 4.221 at 0.05 levels. Since the observed 'F' value on retention measures was highly significant, the adjusted mean difference among command and guided discovery teaching style were statistically significant. Thus, it was evident that retention was influenced during the detraining in both command and guided discovery teaching style.

The observed ' $F$ ' Value (Table II) on acquisition of the skill of ball-bouncing of command and guided discovery group were 9.315 and 11.425 respectively. To be significant at 0.05 levels, for the $\mathrm{Df}=3$ and 56 the required critical value was 2.774 . Since the observed ' $F$ ' values were greater than the required critical value, it was ascertained that the changes occurred across the treatment period was statistically significant.

The observed ' $F$ ' value (Table II) on retention of the skill of ball-bouncing of command teaching style group was 5.878. To be significant at 0.05 level, for the df 3 and 56 the required critical value was 2.774 . Since the observed ' $F$ ' value on the above mentioned criterion measure was greater than the required value it was concluded that the changes occurred across the treatment period was statistically significant. 


\section{Table I}

Computation of Analysis of Covariance of Acquisition and retention of the Skill of Ball-bouncing of Command and Guided Discovery teaching Style Groups Between Pre-test and Post-test

\begin{tabular}{|c|c|c|c|c|c|c|c|c|c|c|c|c|c|c|}
\hline & \multicolumn{2}{|c|}{$\begin{array}{l}\text { Command } \\
\text { teaching } \\
\text { style }\end{array}$} & \multicolumn{2}{|c|}{$\begin{array}{l}\text { Guided } \\
\text { discovery } \\
\text { style }\end{array}$} & \multicolumn{2}{|c|}{ Df } & \multicolumn{2}{|c|}{$\begin{array}{l}\text { Sum of } \\
\text { squares }\end{array}$} & \multicolumn{2}{|c|}{$\begin{array}{l}\text { Mean } \\
\text { square }\end{array}$} & \multicolumn{2}{|c|}{ F-ratio } & \multicolumn{2}{|c|}{ Sig. } \\
\hline & $\begin{array}{l}\text { Ac } \\
\text { qui } \\
\text { siti } \\
\text { on }\end{array}$ & $\begin{array}{l}\text { Ret } \\
\text { enti } \\
\text { on }\end{array}$ & $\begin{array}{c}\text { Acq } \\
\text { uisiti } \\
\text { on }\end{array}$ & $\begin{array}{c}\text { Rete } \\
\text { ntio } \\
\text { n }\end{array}$ & & & $\begin{array}{c}\text { Acqu } \\
\text { isitio } \\
\mathbf{n}\end{array}$ & $\begin{array}{c}\text { Reten } \\
\text { tion }\end{array}$ & $\begin{array}{c}\text { Acqu } \\
\text { isitio } \\
n\end{array}$ & $\begin{array}{l}\text { Ret } \\
\text { enti } \\
\text { on }\end{array}$ & $\begin{array}{l}\text { Acqui } \\
\text { sition }\end{array}$ & $\begin{array}{l}\text { Ret } \\
\text { enti } \\
\text { on }\end{array}$ & $\begin{array}{c}\text { Acq } \\
\text { uisit } \\
\text { ion }\end{array}$ & $\begin{array}{l}\text { Ret } \\
\text { enti } \\
\text { on }\end{array}$ \\
\hline $\begin{array}{l}\text { Pre } \\
- \\
\text { test }\end{array}$ & $\begin{array}{l}27 . \\
013\end{array}$ & $\begin{array}{c}22.9 \\
27\end{array}$ & $\begin{array}{c}27.7 \\
6\end{array}$ & $\begin{array}{c}21.4 \\
93\end{array}$ & $\begin{array}{l}\text { B } \\
: \\
\text { W }\end{array}$ & $\begin{array}{l}1 \\
2 \\
8\end{array}$ & $\begin{array}{c}4.181 \\
244.7 \\
53\end{array}$ & $\begin{array}{c}15.40 \\
8 \\
139.3 \\
19\end{array}$ & $\begin{array}{l}4.181 \\
8.741\end{array}$ & $\begin{array}{c}15 . \\
408 \\
4.9 \\
76\end{array}$ & 0.478 & $\begin{array}{c}3.09 \\
7\end{array}$ & .495 & $\begin{array}{c}0.08 \\
9\end{array}$ \\
\hline $\begin{array}{c}\text { Pos } \\
\text { t- } \\
\text { test }\end{array}$ & $\begin{array}{l}22 . \\
927\end{array}$ & $\begin{array}{c}26.1 \\
27\end{array}$ & $\begin{array}{c}21.4 \\
93\end{array}$ & $\begin{array}{c}22.5 \\
40\end{array}$ & $\begin{array}{l}\text { B } \\
: \\
\text { W }\end{array}$ & $\begin{array}{l}1 \\
2 \\
8\end{array}$ & $\begin{array}{c}15.40 \\
8 \\
139.3 \\
2\end{array}$ & $\begin{array}{c}96.48 \\
1 \\
192.2 \\
65\end{array}$ & $\begin{array}{c}15.40 \\
8 \\
4.976\end{array}$ & $\begin{array}{c}96 . \\
481 \\
6.8 \\
67 \\
\end{array}$ & 3.097 & $\begin{array}{c}14.0 \\
51\end{array}$ & .089 & $\begin{array}{c}0.00 \\
1\end{array}$ \\
\hline $\begin{array}{c}\mathrm{Me} \\
\text { an } \\
\text { gai } \\
\mathrm{n}\end{array}$ & $\begin{array}{c}4.0 \\
86\end{array}$ & 3.2 & $\begin{array}{c}6.26 \\
7\end{array}$ & $\begin{array}{c}1.04 \\
7\end{array}$ & & & $\begin{array}{l}\text { Adjus } \\
\text { ted } \\
\text { sum } \\
\text { of } \\
\text { squar } \\
\text { es }\end{array}$ & $\begin{array}{l}\text { Adjus } \\
\text { ted } \\
\text { sum } \\
\text { of } \\
\text { squar } \\
\text { es }\end{array}$ & $\begin{array}{l}\text { Adjus } \\
\text { ted } \\
\text { sum } \\
\text { of } \\
\text { squar } \\
\text { es }\end{array}$ & $\begin{array}{c}\text { Adj } \\
\text { uste } \\
\text { d } \\
\text { sum } \\
\text { of } \\
\text { squ } \\
\text { ares }\end{array}$ & & & & \\
\hline $\begin{array}{c}\text { Adj } \\
\text { ust } \\
\text { ed } \\
\text { pos } \\
\text { t- } \\
\text { test } \\
\text { me } \\
\text { ans }\end{array}$ & $\begin{array}{l}23 . \\
163\end{array}$ & $\begin{array}{c}25.3 \\
51\end{array}$ & $\begin{array}{c}21.2 \\
57\end{array}$ & $\begin{array}{c}23.3 \\
16\end{array}$ & $\begin{array}{l}\text { W } \\
:\end{array}$ & $\begin{array}{l}2 \\
7\end{array}$ & $\begin{array}{c}26.81 \\
5\end{array}$ & $\begin{array}{c}27.96 \\
5\end{array}$ & $\begin{array}{c}26.81 \\
5\end{array}$ & $\begin{array}{l}27 . \\
965\end{array}$ & $\begin{array}{c}17.72 \\
2\end{array}$ & $\begin{array}{c}26.0 \\
48\end{array}$ & $\begin{array}{l}.000 \\
* *\end{array}$ & $\begin{array}{c}.000 \\
* *\end{array}$ \\
\hline
\end{tabular}

Since significant changes were observed on the selected measures due to command teaching style on the retention of the skill of ball-bouncing, to test the sources for significant changes, the Scheffe's post-hoc test was applied and the result of the same are presented in table III. To test the sources for significant changes of command teaching style on acquisition, the Scheffe's post-hoc test was applied.

The obtained mean differences of command style teaching group on acquisition between stage1 (pretest) and stage2 (end of four weeks) was 1.373; stage1 and stage3 (end of eight weeks) was 2.701; stage1 and stage 4 (post-test) was 4.087; stage2 and stage 3 was 1.333; stage2 and stage 4 was 2.713 ; and stage 3 and 4 was 1.38. Mean differences between stage 1 stage 2 , stage 2 and stage 3 , stage 3 and stage 4 were found insignificant. Whereas mean differences between stage 1 and 3, stages 1 and 4, stages 2 and 4, stage 2 and stage 4 were found significant.

The obtained mean difference of guided discovery teaching group (Table III) on acquisition variable between stage1 (pre-test) and stage 2 (end of four weeks) was 1.44; stage1 and stage3 (end of eight weeks) was 4.567; stage 1 and stage 4 (post-test) was 6.267; stage2 and stage3 was 3.127; stage2 and stage 4 was 4.827; and stage 3 and 4 was 1.7. Mean differences between stage 1 and 2, stages 2 and 3, stage 3 and 4 were found insignificant, whereas mean difference stage 1 and 3 , stage 1 and 4 , stage 2 and 4 were found significant. From the results of table III the mean value of stage 2 (end of 1st week), stage 3 (end of 2nd week) and stage 4 (post-test: end of 4th week) were compared with the pre-test, the mean value of stage 3 and stage 4 were compared with post-test and the mean of stage 3 was compared with the post-test and the mean differences of respective comparisons were compared at what level it was significant and indicated at the significance column. Lower bound and upper bound of $95 \%$ confidence interval were also indicated. 


\section{TABLE II}

Computation of Repeated Measures of Analysis of Variance on Acquisition and Retention of the Skill of Ball-bouncing (Dribbling) of Command and Guided Discovery Teaching Style Groups

\begin{tabular}{|c|c|c|c|c|c|c|}
\hline Variable & Source of Variance & Df & $\begin{array}{c}\text { Sum of } \\
\text { squares }\end{array}$ & $\begin{array}{c}\text { Mean } \\
\text { square }\end{array}$ & F-ratio & Sig. \\
\hline $\begin{array}{c}\text { Acquisition } \\
\text { Command } \\
\text { Teaching style }\end{array}$ & $\begin{array}{l}\text { Between groups } \\
\text { Within groups } \\
\text { Total }\end{array}$ & $\begin{array}{c}3 \\
56 \\
59\end{array}$ & $\begin{array}{l}138.590 \\
277.732 \\
416.322\end{array}$ & $\begin{array}{r}46.197 \\
4.960\end{array}$ & $9.315^{*}$ & .000 \\
\hline $\begin{array}{l}\text { Acquisition } \\
\text { Guided discovery } \\
\text { Teaching style }\end{array}$ & $\begin{array}{l}\text { Between groups } \\
\text { Within groups } \\
\text { Total }\end{array}$ & $\begin{array}{c}3 \\
56 \\
59\end{array}$ & $\begin{array}{l}368.107 \\
601.419 \\
969.526\end{array}$ & $\begin{array}{r}122.702 \\
10.740\end{array}$ & 11.425 & .000 \\
\hline $\begin{array}{c}\text { Retention } \\
\text { Command } \\
\text { Teaching style }\end{array}$ & $\begin{array}{l}\text { Between groups } \\
\text { Within groups } \\
\text { Total }\end{array}$ & $\begin{array}{c}3 \\
56 \\
59\end{array}$ & $\begin{array}{r}85.266 \\
270.780 \\
356.046\end{array}$ & $\begin{array}{r}28.422 \\
4.835\end{array}$ & 5.878 & .001 \\
\hline $\begin{array}{c}\text { Retention } \\
\text { Guided discovery } \\
\text { Teaching style }\end{array}$ & $\begin{array}{l}\text { Between groups } \\
\text { Within groups } \\
\text { Total }\end{array}$ & $\begin{array}{c}3 \\
56 \\
59\end{array}$ & $\begin{array}{l}9.383 \\
405.859 \\
415.242\end{array}$ & $\begin{array}{l}3.128 \\
7.247\end{array}$ & .432 & .731 \\
\hline
\end{tabular}

*Significant at 0.05 level for the $\mathrm{df}$ at $3 \& 45$

(Required critical value $=2.774$

The observed ' $F$ ' value (Table III) on retention of the skill of ball-bouncing of guided discovery teaching style group was 0.432 . To be significant at 0.05 level, for the df 3 and 56 the required critical value was 2.774. Since the observed ' $F$ ' value on the above mentioned criterion measure was less than the required critical value it was concluded that the changes occurred across the treatment period was statistically insignificant. Since the insignificant changes were observed on the selected measures due to guided discovery teaching style on the retention of the skill of ball-bouncing, no post-hoc test of significance was conducted. The results indicated that the acquired skill of ball-bouncing was retained by subjects who were trained by guided discovery style of teaching throughout the four weeks of retention period.

The obtained mean differences between stage 1 and 2 was -1.562 ; stage 1 and 3 was -2.453 ; stage 1 and 4 was -3.200 ; stage 2 and 3 was -0.893 , stage 2 and 4 was -1.640 and stage 3 and 4 was -0.747 . Mean difference between stages 1 and 2, stage 1 and 3, stage 2 and 3 and stage 3 and 4 were found insignificant, whereas mean difference between stage 1 and 4, significant. From the results it may be concluded that acquired skill of ballbouncing was retained by the learner up to stage 3 that is for a period of two weeks only by way of command teaching style.

\section{Table III}

Multiple Comparisons Using Scheffe's Post Hoc Test on Difference between Treatment Means at Various Stages on Acquisition and Retention of the Skill of Ball Bouncing (Dribbling) of Command Style and guided Teaching Groups

\begin{tabular}{|c|c|c|c|c|c|c|}
\hline \multirow{2}{*}{ Variables } & Group & Group & $\begin{array}{c}\text { Mean } \\
\text { diff }\end{array}$ & Sig & Lower bound & $\begin{array}{c}\text { Opper } \\
\text { bound }\end{array}$ \\
\hline & & & & & & \\
\hline & 1.00 & 2.00 & 1.373 & .422 & -.971 & 3.717 \\
Acquisition & 1.00 & 3.00 & $2.707^{*}$ & .017 & .363 & 5.051 \\
Command & 1.00 & 4.00 & $4.087^{*}$ & .000 & 1.743 & 6.431 \\
teaching & 2.00 & 3.00 & 1.333 & .449 & -1.010 & 3.677 \\
Style & 2.00 & 4.00 & $2.713^{*}$ & .017 & .367 & 5.057 \\
& 3.00 & 4.00 & 1.380 & .418 & -.964 & 3.724 \\
\hline
\end{tabular}




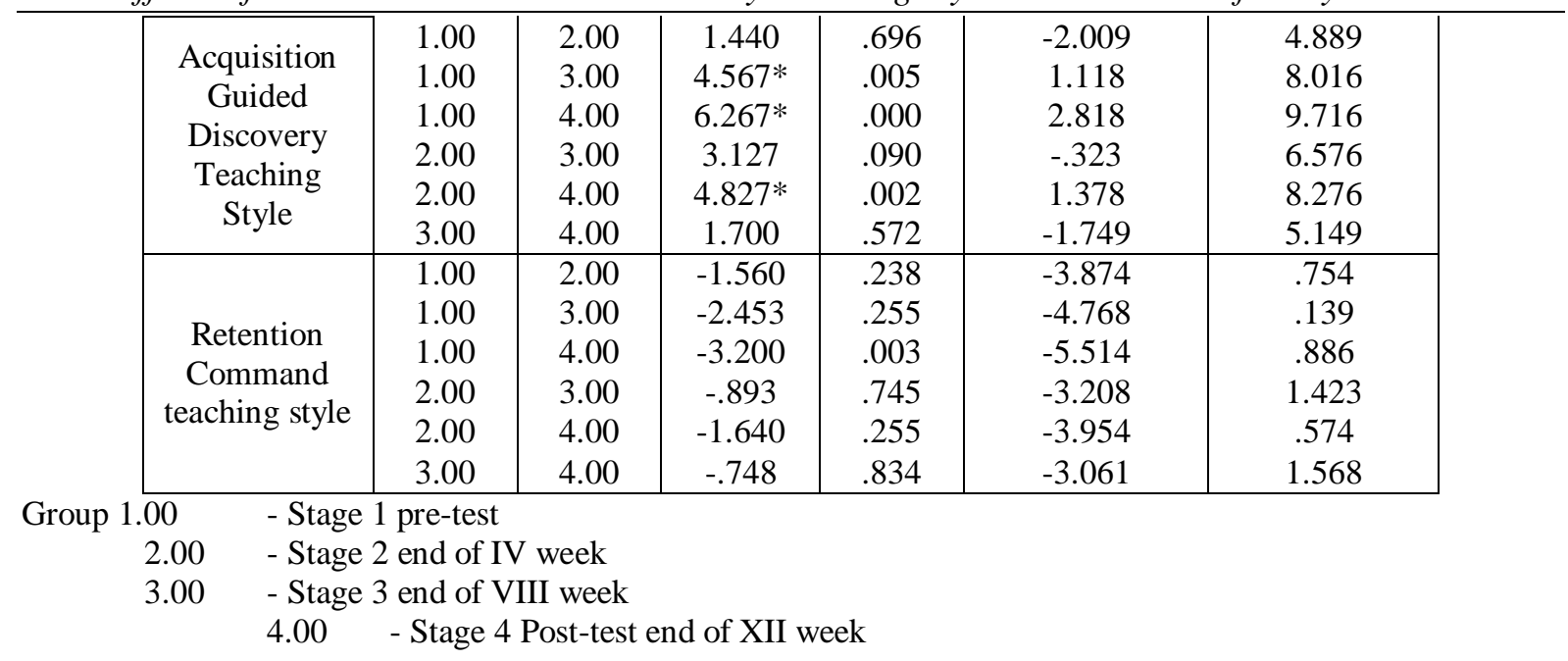

\section{V.}

Conclusion

In the light of the study undertaken with certain limitations imposed by the experimental conditions the following conclusions were drawn from the obtained results.

1. The practice of scientifically structured twelve weeks of command and guided discovery teaching style may help to acquire the skill of ball-bouncing.

2. Eight weeks of command and guided discovery teaching style may be sufficient to acquire the skill of ballbouncing.

3. For the retention of the acquired psychomotor skill under the guided discovery style, a child-centered teaching approach is superior when compared with command style teaching approach, a teacher-centered teaching approach.

\section{Recommendations}

Following are the recommendations:

1. Formal physical education programme in the form of movement education shall be included in the curriculum of primary school children in India.

2. As the physical education teachers are not trained in various types of teaching styles in India, this training may be included in the Physical Education Teacher Education curriculum.

\section{Reference}

[1] Mosston, M., \& Ashworth, S. (1990). The Spectrum of Teaching Styles: From Command to Discovery (New York: Longman, 1990)

[2] Mosston, M., \& Ashworth, STeaching Physical Education ( $5^{\text {th }}$ Ed.) (New York: Benjamin Cummings, 2002).

[3] Hoffman,s. (1971). Traditional Methodology; Prospects for Change Quest. 15, 1971-Winter (Winter).

[4] Salter, G. Quality Teaching in Physical Education: A New Zealand Perspective, 1992 (Source: http://www.gare.edu.au/92pap/salted 92283.txt).

[5] Kim, U., Triandis, H., Kangitcibasi, C., Choi, S.C., \& Yoon, Collectivism (Newbury Park, CA: Sage, 1994 